\title{
The Effectiveness of Lime-based Amendments and Bauxite Residues at Removing Phosphorus from Piggery Effluent
}

\author{
D. M. Weaver \& G. S. P. Ritchie
}

\begin{abstract}
Piggery effluent may contribute to the eutrophication of waterways, if it is not treated before disposal, because of high levels of phosphorus. Limes and red muds (a residue from bauxite refining) were used to remove phosphorus from piggery effluent ( $41 \mathrm{mg}_{\text {litre }}{ }^{-1}$ total $P$ ). Lime-based amendments were more effective than the red muds at removing phosphorus when compared at the same liquid: solid ratios. Based on laboratory data, the cost of treating effluent increased rapidly as the final required phosphorus concentration decreased to less than $4 \mathrm{mg}$ litre ${ }^{-1}$. Kiln dust was the cheapest amendment tested down to $2 \mathrm{mg}$ litre ${ }^{-1}$. Hydrated lime was able to clarify and flocculate the effluent to $1 \mathrm{mg}$ litre ${ }^{-1}$ within $60 \mathrm{~min}$. The re-useability of all limes may be determined by a simple pH test. Red mud could be used to remove phosphorus when its pH was lowered to 6.0-6.5 and it is used at liquid: solid ratios <20:1.
\end{abstract}

\section{INTRODUCTION}

The waste effluent from piggeries contains high levels of phosphorus $(\mathrm{P})$ and nitrogen (Baxter, 1984) which may cause eutrophication of waterways, if the waste is not treated before disposal.

A traditional method of treatment and disposal of piggery waste is spray irrigation after settling in ponds (Raper, 1983). This approach is suitable for soils with high capacities to adsorb $\mathbf{P}$ and where it is easy to establish plant growth. However, some piggeries are situated on sandy soils, which have little capacity to prevent the leaching of $P$ into waterways, and therefore some form of pre-treatment is required before disposal. 
The aim of this work was to compare the ability of several different amendments to reduce the $P$ content of ponded pig effluent to $<1 \mathrm{mg}$ litre $^{-1}$. The amendments investigated were either lime based or manufactured from red mud (a residue from bauxite refining). Both lime (Kox, 1981) and red mud (Shiao \& Akashi, 1977) have been shown to be capable of removing $P$ from other types of waste product or $\mathrm{P}$ solutions.

\section{MATERIALS AND METHODS}

Piggery effluent was collected from the outflow of the last of three settling ponds of an intensive piggery situated on sandy soils of the Swan Coastal Plain in South Western Australia. The effluent was divided into 1 litre portions and frozen. It was thawed overnight as required. Because of the presence of solids in the effluent, it was always mixed by a magnetic stirrer when it was dispensed. The effluent contained $41 \mathrm{mg} \mathrm{litre}^{-1}$ total $P$, and $20.3 \mathrm{mg}$ litre $^{-1}$ dissolved inorganic $\mathrm{P}$, and $0.03 \%$ suspended solids (American Public Health Association, 1971). Hydrated lime, quicklime and kiln dust were obtained from Hydrated Lime Pty Ltd, Malaga, W.A. (Table 1). Quicklime ground to $<180 \mu \mathrm{m}$ was also used in the experiments.

TABLE 1

Chemical and Physical Properties of the Lime-based Amendments

\begin{tabular}{lccc}
\hline & Hydrated lime & Quicklime & Kiln dust \\
\hline $\mathrm{CaO}$ & $69 \cdot 0$ & $82 \cdot 5$ & $20 \cdot 0-40 \cdot 0$ \\
Available lime & $64 \cdot 0$ & $75 \cdot 5$ & $25 \cdot 0-30 \cdot 0$ \\
$\mathrm{MgO}$ & $4 \cdot 0$ & $5 \cdot 4$ & $0 \cdot 8-4 \cdot 0$ \\
$\mathrm{CaCO}_{3}$ & - & - & $4 \cdot 0-71 \cdot 0$ \\
$\mathrm{MgCO}_{3}$ & - & - & $5 \cdot 0-11 \cdot 0$ \\
$\mathrm{LOI}$ & $22 \cdot 0$ & $1 \cdot 2$ & - \\
Particle size & $<150 \mu \mathrm{m}$ & $<600 \mu \mathrm{m}$ & $<45 \mu \mathrm{m}$ \\
\hline
\end{tabular}

Red mud was obtained from Alcoa of Australia, Kwinana, W.A., from stockpiles. Raw red mud was collected from a nearby holding pond. The muds included were raw mud treated with $5 \%$ gypsum, or treated with $7 \%$ ferrous sulphate (copperas), a by-product of the titanium extraction industry. The red mud was dried at $70^{\circ} \mathrm{C}$ and then passed through a $2 \mathrm{~mm}$ sieve. Typical Kwinana red mud contains $20 \% \mathrm{Al}_{2} \mathrm{O}_{3}, 27 \% \mathrm{SiO}_{2}, 31 \%$ $\mathrm{Fe}_{2} \mathrm{O}_{3}, 4 \cdot 5 \% \mathrm{CaO}, 3 \% \mathrm{TiO}_{2}, 7 \mathrm{ppm}\left(\mu \mathrm{g} \mathrm{g}^{-1}\right)$ bicarbonate extractable $\mathrm{P}$ and has a loss on ignition of $11.5 \%$ (Robson, 1982). 


\section{Experimental procedures}

Each amendment was tested for its ability to remove $\mathrm{P}$ from the piggery effluent by mixing them with effluent at the liquid:solid ratios shown in Table 2. The amendments were tested for their capacity to remove $\mathbf{P}$ by reusing each amendment to treat five sequential aliquots of fresh effluent. Fresh effluent and fresh amendment were shaken, end over end, for $30 \mathrm{~min}$, then centrifuged. The supernatant was removed and filtered $(0.45 \mu \mathrm{m})$ for analysis and fresh effluent was added to the resultant sludge. This was repeated a further four times. If the results of re-using the amendment to treat five sequential aliquots of fresh effluent showed that the $P$ concentration did not reach $<1 \mathrm{mg}$ litre $^{-1}$, then an aliquot of effluent was re-treated sequentially with five portions of fresh amendment. This was done by shaking fresh amendment with fresh effluent, end over end, for $30 \mathrm{~min}$, then centrifuging. The supernatant (treated effluent) was removed, an aliquot was filtered $(0.45 \mu \mathrm{m})$ and retained for analysis while the remainder was added to fresh amendment at the correct ratio (Table 2) for re-treatment. This was repeated a further four times.

Lime was tested for its ability to flocculate, settle and remove $\mathrm{P}$ from

TABLE 2

Liquid:solid Ratios (litre:kg), Contact Times and Number of Sequential

Steps used in the Experiments

\begin{tabular}{lccc}
\hline \multicolumn{3}{c}{ Amendment } & \multicolumn{3}{c}{\begin{tabular}{c} 
Experiment \\
\cline { 2 - 4 }
\end{tabular}} & $\begin{array}{c}\text { Re-use } \\
\text { amendment }\end{array}$ & $\begin{array}{c}\text { Re-treat } \\
\text { effluent }\end{array}$ & $\begin{array}{c}\text { Effect of } \\
\text { contact time }\end{array}$ \\
\hline Hydrated lime & $5: 1,50: 1$, & - & \\
Quicklime & $100: 1,200: 1$ & & \\
(ground/unground) & $5: 1,50: 1$, & - & \\
Kiln dust & $100: 1,200: 1$ & $5: 1$ & $5: 1$ \\
Raw red mud & $5: 1,10: 1,25: 1$, & $5: 1$ \\
Gypsum-treated & $50: 1$ & $5: 1$ & $10: 1$ \\
red mud & $5: 1$ & & $20: 1$ \\
& $5: 1$ & $5: 1$ \\
Copperas-treated & & $5: 1$ & $10: 1$ \\
red mud & $5: 1$ & & $20: 1$ \\
& & 5 & 1 \\
Number of steps & 5 & $30 \mathrm{~min}$ & $15 \mathrm{~min}$ to \\
Time of contact & $30 \mathrm{~min}$ & & $29 \mathrm{~h}$
\end{tabular}


effluent. Effluent was placed in a 50-ml measuring cylinder (height, $153 \mathrm{~mm}$; diameter, $20.4 \mathrm{~mm}$ ) and hydrated lime was added as a $20 \%$ dry weight slurry (Payne, 1986) at liquid:solid ratios of 50:1, 100:1 and 200:1. The cylinder was inverted three times and the 'floc' volume measured at certain times up to $2 \mathrm{~h}$. The filtered supernatant $(0.45 \mu \mathrm{m})$ was analysed for $\mathrm{P}$ and $\mathrm{pH}$.

Red mud was also tested to see what effect contact times had on $P$ removal, at different effluent:mud ratios (Table 2). Red mud and effluent were shaken, end over end, after which they were centrifuged, $\mathrm{pH}$ was measured and the filtered supernatant $(0.45 \mu \mathrm{m})$ was analysed for $P$.

Raw red mud was tested for its ability to remove $P$ from effluent after refluxing with $5.8 \% \mathrm{HCl}$ (dry mud basis). The raw red mud was refluxed (Shiao \& Akashi, 1977), washed, dried, ground $(<180 \mu \mathrm{m})$ and shaken with effluent at a ratio of 20:1 for various times from $15 \mathrm{~min}$ to $29 \mathrm{~h}$. This method was compared with adding an equivalent amount of $\mathrm{HCl}$ in a $1-\mathrm{ml}$ aliquot to a raw red mud $(<180 \mu \mathrm{m})$ effluent/slurry and shaking for the same times at the same ratio. A 1-ml aliquot of deionised water was added to the refluxed system to make the ratios identical. After each time the samples were centrifuged, $\mathrm{pH}$ measured and the filtered supernatant $(0.45 \mu \mathrm{m})$ was analysed for $\mathrm{P}$.

Raw red mud $(<180 \mu \mathrm{m})$ was tested for its ability to remove $\mathrm{P}$ from effluent in the presence of $0-8.9 \% \mathrm{HCl}$ (dry mud basis). Samples were shaken end over end for $3 \mathrm{~h}$, at a ratio of $20: 1$, then centrifuged, $\mathrm{pH}$ measured and the filtered supernatant $(0.45 \mu \mathrm{m})$ was analysed for $P$.

\section{Analyses}

All $\mathrm{P}$ concentrations were determined colorimetrically using the molybdenum blue method of John (1970). All filtered solutions $(0.45 \mu \mathrm{m})$ were analysed for dissolved inorganic $P$ and total $P$. Total $P$ was determined after digestion with perchloric acid. Total $\mathrm{P}$ and dissolved inorganic $\mathrm{P}$ concentrations in the filtered solutions were not significantly different $(p<0.05)$. $\mathrm{pH}$ was measured with a Corning $120 \mathrm{pH}$ meter, using a combination electrode. All experiments had three replicates.

\section{RESULTS}

\section{Lime amendments}

The volume of effluent that could be treated to reduce its $\mathrm{P}$ concentration to $<1 \mathrm{mg}$ litre $^{-1}$ depended on the type of lime used (Fig. 1(a)). One kilogram of hydrated lime, or ground quicklime, was capable of reducing the $\mathrm{P}$ 
(a)

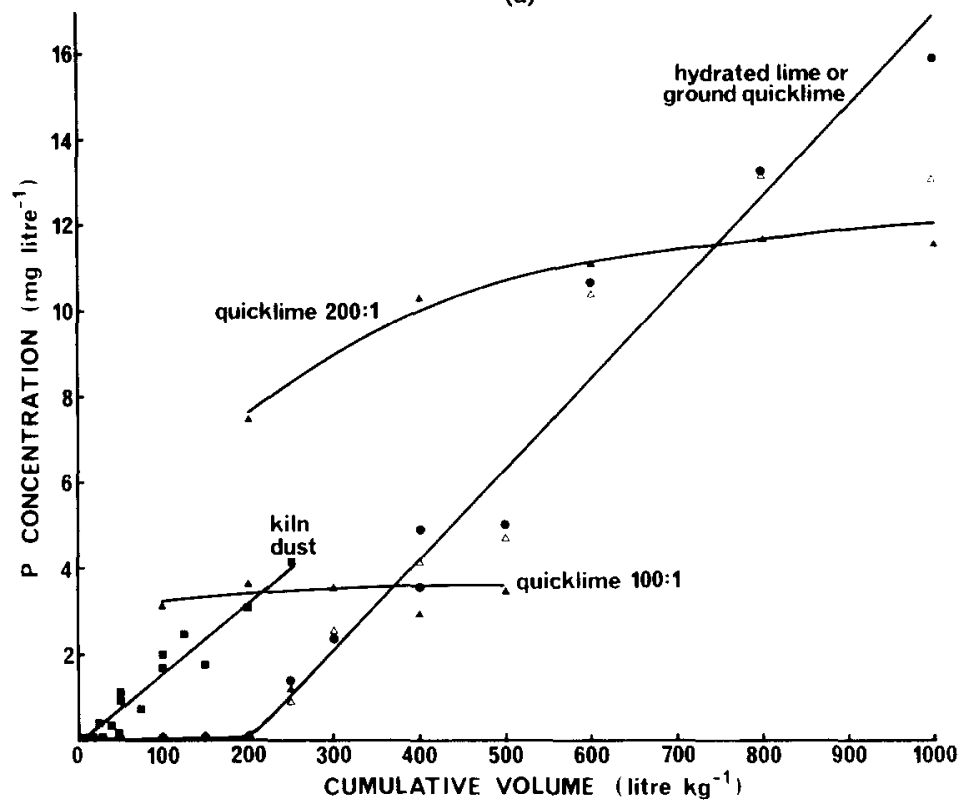

(b)

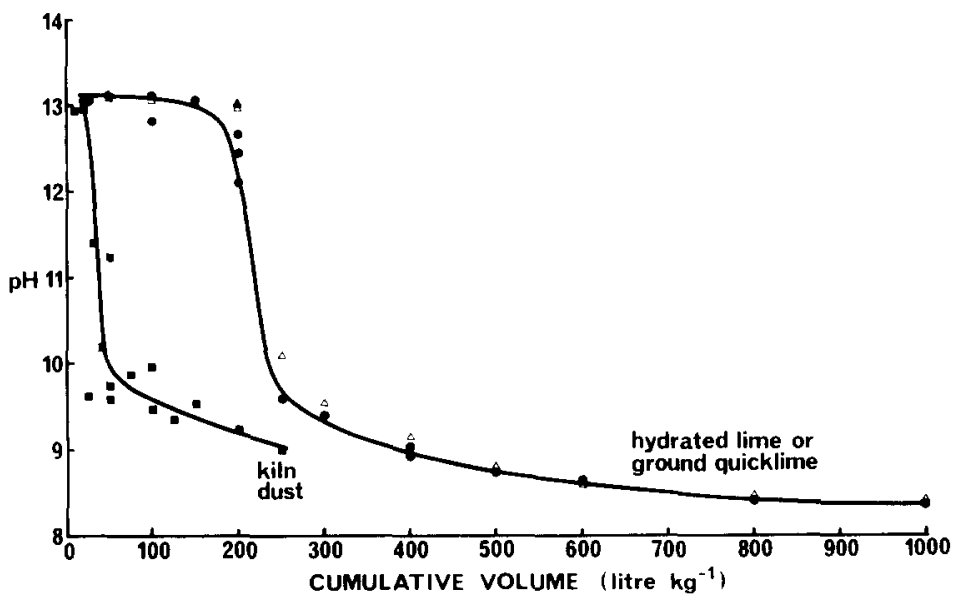

Fig. 1. The phosphorus concentration in $\mathrm{mg} \mathrm{litre}^{-1}$ (a) and $\mathrm{pH}$ (b) of effluent treated with kiln dust $(\boldsymbol{\square})$, hydrated lime $(\boldsymbol{O})$, quicklime $(\boldsymbol{\Delta})$ and ground quicklime $(\triangle)$ as a function of the cumulative volume (litres) of effluent added to each amendment. 
concentration of 200 litres of effluent to $<1 \mathrm{mg}$ litre $^{-1}$, whereas an equal amount of kiln dust could only lower the $P$ concentration of 50 litres of effluent to $<1 \mathrm{mg}$ litre $^{-1}$. It did not matter if the effluent was added to the amendment as one volume or several smaller volumes, except for unground quicklime. The $\mathrm{pH}$ of the treated effluent depended on the volume of effluent that had been in contact with the different lime amendments (Fig. 1(b)). The marked drop in $\mathrm{pH}(3.5 \mathrm{pH}$ units) represents the neutralisation of the buffering ability of the lime and coincided with a rapid increase in $\mathbf{P}$ concentration. The change in $\mathrm{pH}$ and $\mathrm{P}$ concentration was also associated with a change in the colour of the solution, from clear and colourless, to clear but light brown. Figure 2 shows that there was a consistent logarithmic relationship between $\mathrm{P}$ concentration in the treated effluent and $\mathrm{pH}$, and it was independent of the source of lime.

Irrespective of the ratio used, $>85 \%$ of settling had occurred after $60 \mathrm{~min}$ (Fig. 3). $\mathrm{pH}$ values of the remaining supernatant were $12 \cdot 5-13 \cdot 0$ and $\mathrm{P}$ concentrations were $<1 \mathrm{mg}$ litre $^{-1}$.

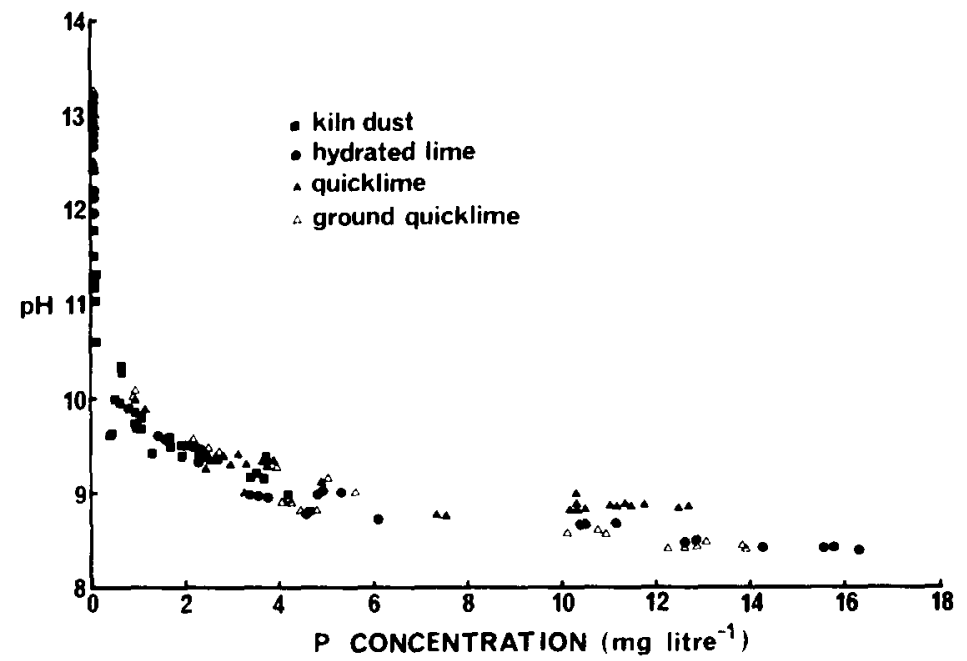

Fig. 2. The relationship between phosphorus concentration ( $\mathrm{mg}$ litre ${ }^{-1}$ ) and $\mathrm{pH}$ of effluent after treatment with kiln dust $(\boldsymbol{D})$, hydrated lime $(\boldsymbol{O})$, quicklime $(\boldsymbol{\Delta})$ and ground quicklime $(\triangle)$.

\section{Red mud amendments}

None of the red muds lowered the $\mathrm{P}$ concentration of the effluent to $<1 \mathrm{mg}$ litre $^{-1}$ at ratios $>5: 1$ and contact times of $<30 \mathrm{~min}$. When the effluent was sequentially re-treated with fresh red mud, the gypsum- and copperastreated muds decreased the effluent $P$ concentration to $<1 \mathrm{mg} \mathrm{litre}^{-1}$ after the second addition of fresh red mud (Fig. 4(a)). Raw red mud released $P$ into 


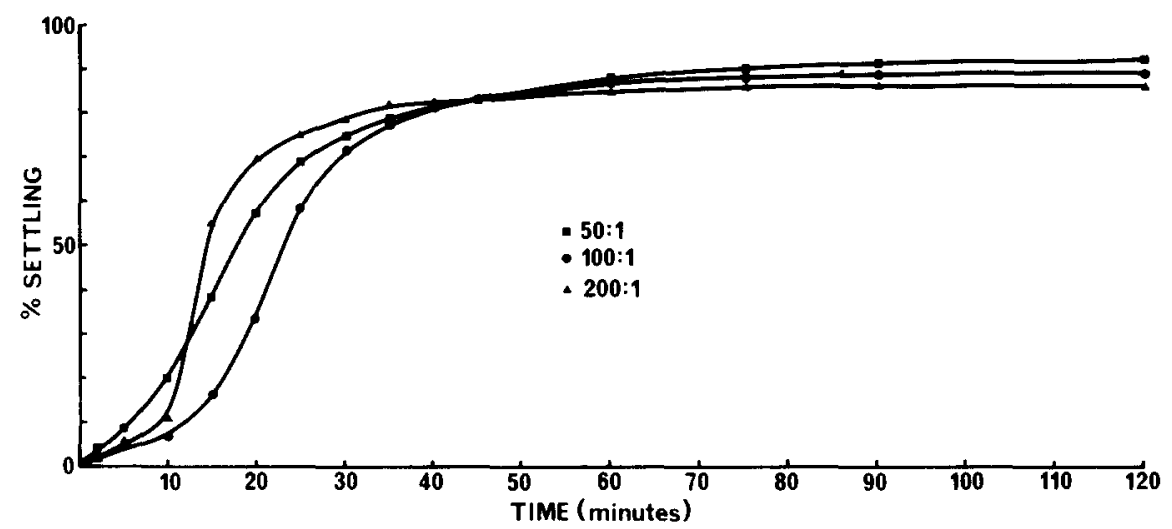

Fig. 3. The settling behaviour of effluent after treatment with hydrated lime at ratios of 50:1 (a), 100:1 (O) and 200:1 (A).
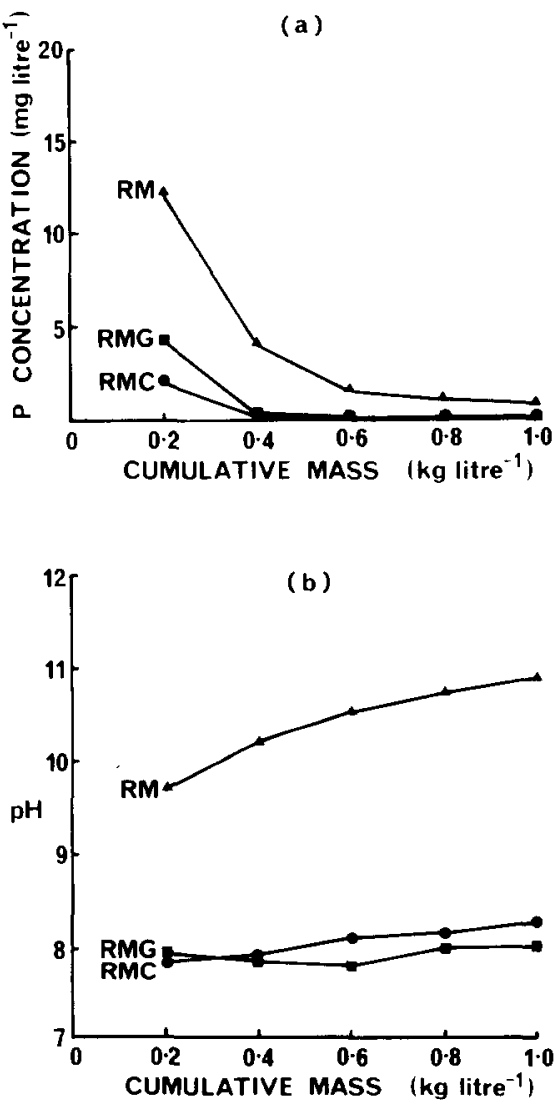

Fig. 4. The phosphorus concentration in $\mathrm{mg}$ litre ${ }^{-1}$ (a) and $\mathrm{pH}$ (b) of effluent after successive re-treatment with raw red mud, RM (A), gypsum-treated red mud, RMG $(\boldsymbol{D})$ and copperas-treated red mud, RMC (O). 
solution (data not shown) and the P concentration of the treated effluent approached $1 \mathrm{mg}$ litre $^{-1}$ after five successive additions of fresh raw red mud (Fig. 4(a)). The pH of the effluent approached that of the red mud after sequential treatment with fresh amendment (Fig. 4(b)).

The $\mathrm{P}$ concentration of the effluent decreased as the contact time with the red mud amendments increased (Fig. 5(a), 5(b)). At each ratio tested, copperas-treated mud was the most effective at removing $\mathrm{P}$. The $\mathrm{pH}$ remained constant with time for all the red mud amendments (data not shown).

Raw red mud, refluxed with $5.8 \%$ (dry mud basis) hydrochloric acid, was not as effective at removing $P$ from the effluent as the raw red mud mixed with $\mathrm{HCl}$ at a rate equivalent to $5.8 \%$ (Fig. 6(a)). The effectiveness of the acid-refluxed mud improved with time (Fig. 6(a)), but it never decreased P

(a)

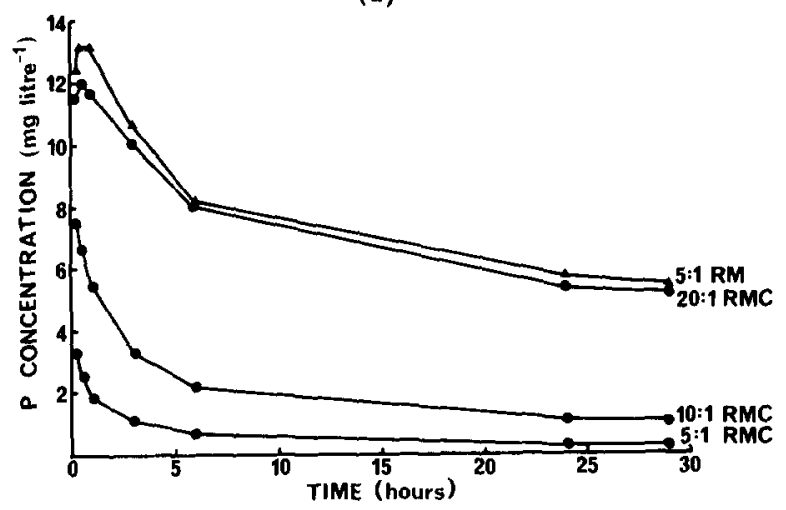

(b)

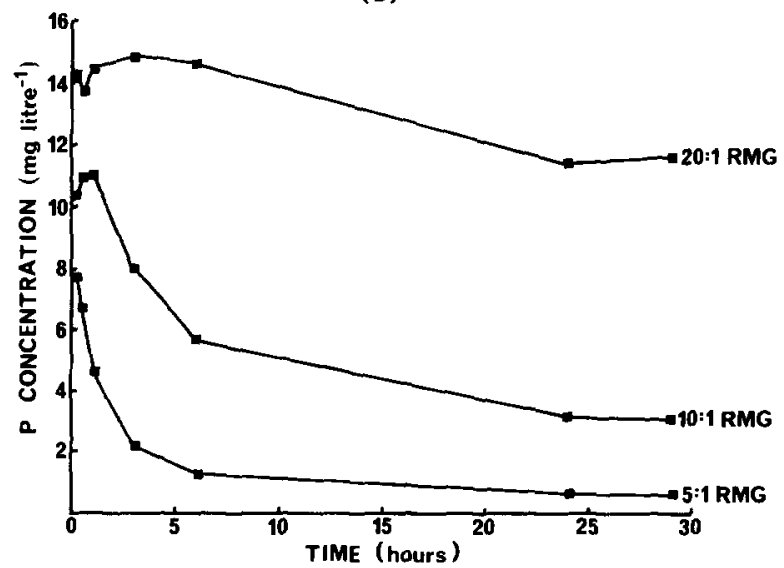

Fig. 5. The effect of contact time (h) and liquid : solid ratio on the phosphorus concentration (mg litre ${ }^{-1}$ ) of effluent treated with (a) raw red mud, RM ( $\Delta$ ) and copperas-treated red mud, RMC (O) and (b) gypsum-treated red mud, RMG ( $\square$ ). 
(a)

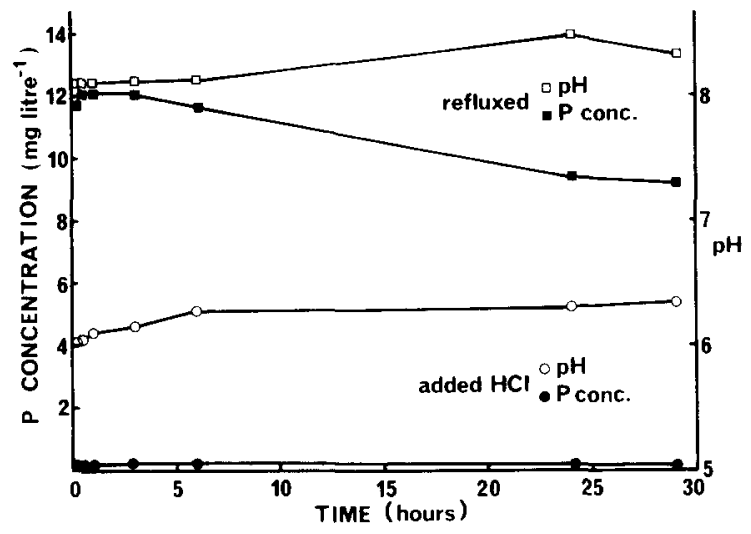

(b)

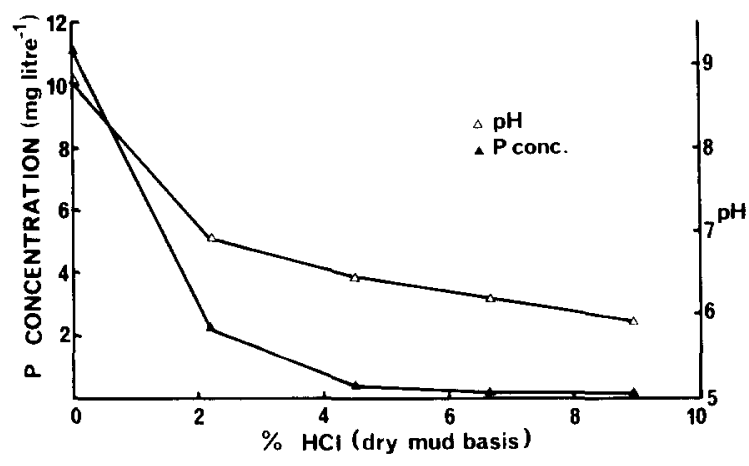

Fig. 6. (a) The effect of contact time on $\mathrm{pH}$ (open symbols) and phosphorus concentration in mg litre ${ }^{-1}$ (closed symbols) for refluxed red mud ( $\square$ ) and for a mud/effluent slurry with added $\mathrm{HCl}(\mathrm{O})$. (b) The effect of the level of hydrochloric acid addition (\% dry weight basis) to a mud/effluent slurry on $\mathrm{pH}$ (open symbols) and phosphorus concentration in $\mathrm{mg}$ litre ${ }^{-1}$ (closed symbols).

concentrations to $<1 \mathrm{mg}$ litre ${ }^{-1}$. In contrast, the effluent/mud slurry mixed with acid decreased the $\mathrm{P}$ concentration of the effluent to $<1 \mathrm{mg}^{\text {litre }}{ }^{-1}$ within $15 \mathrm{~min}$ of contact. There was also a marked difference in $\mathrm{pH}$ of the effluent after treatment with the two acidified red muds. Neither $\mathrm{pH}$ varied much with time, however (Fig. 6(a)). The concentration of $\mathrm{P}$ in solution and the $\mathrm{pH}$ decreased when the amount of acid mixed with the effluent/mud slurry was varied between $0 \%$ and $8.9 \%$ (Fig. $6(\mathrm{~b})$ ).

\section{Economic considerations}

The cost, in Australian Dollars (\$) per thousand litres of effluent, to reduce $\mathrm{P}$ concentration was estimated for a piggery with an annual volume of effluent 


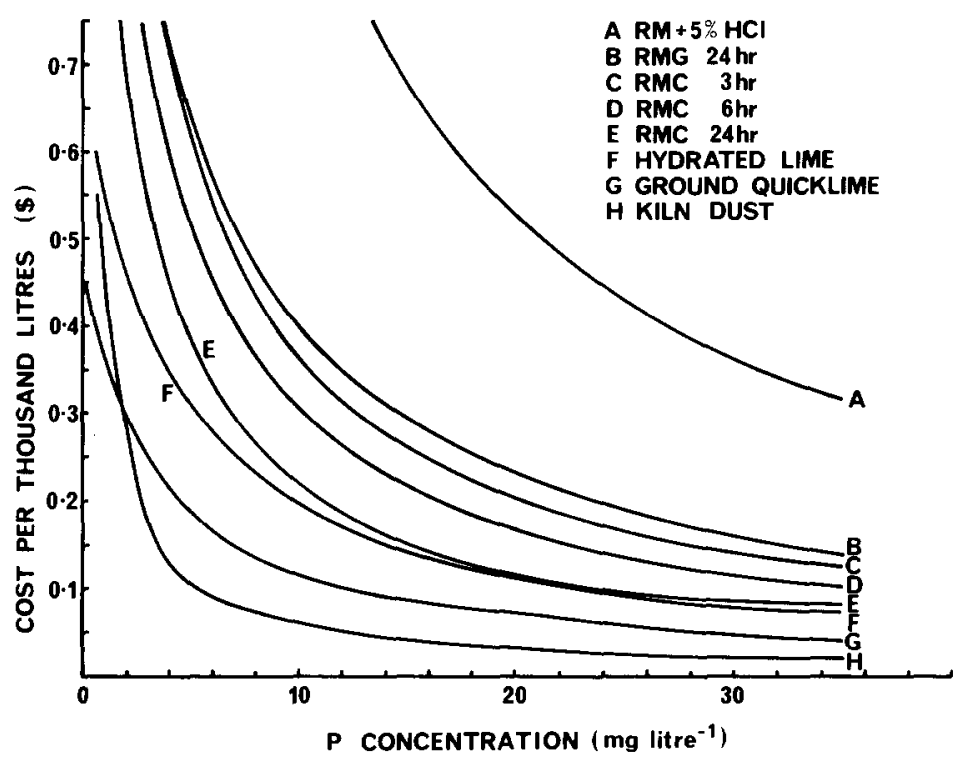

Fig. 7. Predicted phosphorus concentration ( $\mathrm{mg}$ litre ${ }^{-1}$ ) of effluent (laboratory-based data) for a given cost in Australian Dollars (\$) per thousand litres of effluent after treatment with A: raw red mud, (RM) plus 5\% $\mathrm{HCl}$; B: Gypsum-treated red mud, RMG ( 24 h contact time); C: copperas-treated red mud, RMC ( $3 \mathrm{~h}$ contact time); D: copperas-treated red mud, RMC ( $6 \mathrm{~h}$ contact time); E: copperas-treated red mud, RMC ( 24 h contact time); F: hydrated lime; G: ground quicklime; $\mathrm{H}$ : kiln dust.

of $4.07 \times 10^{8}$ litre (Fig. 7). It was assumed that the total P concentration of the effluent would be $40 \mathrm{mg}$ litre ${ }^{-1}$ after passing through the third settling pond. This represents $16 \cdot 3$ tonnes of $P$ per year (R. B. Humphries, pers. comm.). The amendment costs, based on October 1986 prices, including transport in dollars per tonne of amendment, were: hydrated lime (140), quicklime (90), kiln dust (37), red muds (8) and red mud plus $5 \% \mathrm{HCl}(82)$. Transport costs for lime vary depending on the type of lime and how it is transported. The cost of grinding quicklime and the transport costs for $\mathrm{HCl}$ have not been included. The running costs of a treatment plant have not been considered.

For all the amendments, the cost per thousand litres of treating the effluent increased rapidly as the final, required $\mathrm{P}$ concentration decreased from 4 to $0.5 \mathrm{mg}$ litre $^{-1}$ (Fig. 7). The cheapest amendments were kiln dust and ground quicklime, and the most expensive were the red muds. Even though red mud is cheaper than lime (per tonne), much larger quantities are required to achieve the same effluent concentration. It must be emphasised that Fig. 7 is based upon laboratory data and, as such, translation to the field is difficult. 


\section{DISCUSSION}

Lime-based amendments were more effective than red mud at removing $\mathbf{P}$ from piggery effluent when compared at the same liquid:solid ratios. Despite the much higher price of the limes, they were more cost effective than the red muds because of the smaller quantities required to reduce the $P$ concentration to $<1 \mathrm{mg}$ litre $^{-1}$. Kiln dust was the cheapest amendment tested down to $2 \mathrm{mg} \mathrm{P}$ litre ${ }^{-1}$. When the desired $\mathrm{P}$ concentration is $<2 \mathrm{mg}$ litre $^{-1}$ ground quicklime is more cost effective; however, large initial costs for the handling of ground quicklime may be required.

If the eutrophication of waterways is to be prevented, the criteria for estimating the effectiveness of an amendment to remove $P$ must include both high $P$ removal and low residual phosphorus concentration. For example, at a liquid :solid ratio of 1000:1 (litre: $\mathrm{kg}$ ), $40 \mathrm{~kg}$ of $\mathrm{P}$ was removed per tonne of hydrated lime, but the final solution concentration was approximately $16 \mathrm{mg}$ $P$ litre $^{-1}$. On the other hand, for the effluent concentration to be $<1 \mathrm{mg}$ $P$ litre ${ }^{-1}$, only $8 \mathrm{~kg}$ of $\mathbf{P}$ could be removed per tonne of hydrated lime. Therefore, the removal rates achieved in our work may seem low in comparison with values reported for other types of waste (e.g. Kox, 1981; Loehr \& Johanson, 1974), but this is because of our choice of criteria of effectiveness.

The relative effectiveness of the different limes depended on their $\mathrm{CaO}$ content (i.e. neutralisation capacity) and the surface area of particles $>180 \mu \mathrm{m}$. The action of lime on piggery effluent appeared to be twofold; partly to precipitate $P$, and partly to flocculate suspended solids and precipitate or adsorb soluble organic compounds.

$\mathrm{A} \mathrm{pH}>10$, after treatment with lime, assured a P concentration of $<1 \mathrm{mg}$ litre $^{-1}$ in the effluent. Kox (1981) found a similar relationship for P removal from calf manure, whereas Loehr \& Johanson (1974) found only a broad relationship between $\mathrm{pH}$ and desired phosphate removal from duck wastes.

Raw red mud and mud treated with gypsum, or copperas, were not suitable for removing $P$ from effluent, because very low liquid:solid ratios were required to reduce $\mathbf{P}$ concentrations to $<1 \mathrm{mg}$ litre ${ }^{-1}$. Two additions of gypsum-, or copperas-treated mud at a ratio of 5:1 removed $0.1 \mathrm{~kg} P$ per tonne of mud and decreased the $P$ concentration to $<1 \mathrm{mg}$ litre ${ }^{-1}$. The maximum removal of $P\left(0.8 \mathrm{~kg}\right.$ tonne $\left.{ }^{-1}\right)$ occurred when sufficient hydrochloric acid was mixed with raw mud/effluent slurry to give a $\mathrm{pH}$ of 6.0-6.5. Barrow (1982) also showed that the adsorption capacity of red mud increased as its $\mathrm{pH}$ was decreased and found that $0.4 \mathrm{~kg}$ P per tonne were removed at $\mathrm{pH} 7$. No information was available for $\mathrm{pH}<6.5$.

Acid-refluxed mud did not appear to be a suitable amendment for $\mathbf{P}$ removal from pig effluent under the conditions tested. Shiao \& Akashi (1977) 
studied the adsorption of $\mathbf{P}$ from simple orthophosphate solutions by acidrefluxed red mud. Red mud refluxed with $5.8 \%$ (interpolated) $\mathrm{HCl}$ (dry mud basis) reduced the $P$ concentration from $8.2 \mathrm{mg} \mathrm{litre}^{-1}$ to $6.5 \mathrm{mg}$ litre ${ }^{-1}$ after 60 min contact, at a ratio of approximately $100: 1$. This is equivalent to the removal of $0.2 \mathrm{~kg} \mathrm{P}$ per tonne of red mud, which is similar to our work and that of Barrow (1982). Much higher levels of $P$ removal ( $7.2 \mathrm{~kg} \mathrm{P}$ tonne ${ }^{-1}$ ) were found with red mud refluxed with $25 \% \mathrm{HCl}$ (dry mud basis) at a ratio of $500: 1$, when the $P$ concentration was reduced from $16.3 \mathrm{mg}$ litre ${ }^{-1}$ to $1.1 \mathrm{mg}$ litre $^{-1}$ after 120 min contact time. It is not possible to make direct comparisons of removal rates other than at levels of $\mathrm{HCl}$ addition, since Shiao \& Akashi (1977) do not report the pH of their acid refluxed muds or of supernatant solutions.

In conclusion, lime appears suitable for $\mathrm{P}$ removal from piggery effluent, not only for its ability to remove $P$, but also because it can flocculate and clarify the effluent within $60 \mathrm{~min}$. The re-useability of the lime may be determined by a simple $\mathrm{pH}$ test. Red mud is only suitable for $\mathrm{P}$ removal from piggery effluent when its $\mathrm{pH}$ has been lowered to $6.0-6.5$ and it is used at a liquid:solid ratio $<20: 1$.

\section{ACKNOWLEDGEMENTS}

The authors wish to thank the Department of Conservation and the Environment, Perth, Western Australia, for funding this research and Peter Kiss for technical assistance.

\section{REFERENCES}

American Public Health Association, (1971). Standard methods for the examination of water and wastewater, (13th edn), Am. Public Health Assoc., New York.

Barrow, N. J. (1982). Possibility of using caustic residue from bauxite for improving the chemical and physical properties of sandy soils. Aust. J. Agric. Res., 33, $275-85$.

Baxter, S. (1984). Intensive pig production: Environmental management and design, Granada Publishing, London.

John, M. K. (1970). Colorimetric determination of phosphorus in soil and plant materials with ascorbic acid. Soil Sci., 109, 214-20.

Kox, W. M. A. (1981). Phosphorus removal from calf manure under practical conditions. Agric. Wastes, 3, 7-19.

Loehr, R. C. \& Johanson, K. J. (1974). Phosphate removal from duck farm wastes. $J$. Wat. Pollut. Control Fed., 46, 1692-714.

Payne, R. W. (1986). A technique for the removal of particulate solids and phosphorus from piggery effluent. In Proceedings of a symposium 'Water 
Quality and Land Use', Australian Water and Wastewater Association, Perth, Western Australia, 39-43.

Raper, W. G. G. (1983). Water pollution-sewage-recycling. In Phosphorus in Australia, ed. by Costin, A. B. \& Williams, C. H. Centre for Resource and Environmental Studies, Australian National University, Canberra Publishing and Printing Co.

Robson, B. (1982). Use of Bayer process solid residues (red mud and process sand) for the renovation of wastewater-in particular the removal of ammonium. MSc. thesis, Murdoch University, Western Australia.

Shiao, S. J. \& Akashi, K. (1977). Phosphate removal from aqueous solution from activated red mud. J. Wat. Pollut. Control Fed., 49, 280-5. 